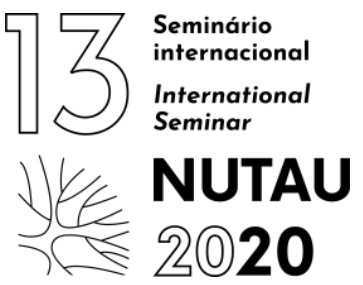

\title{
Árvores urbanas como um recurso natural: Desafios e oportunidades
}

\author{
William Schleizer \\ Delta Institute, CEO \\ wschleizer@delta-institute.org
}

\section{RESUMO}

Apresenta a experiência do Instituto Delta, que colabora com comunidades da Região Centro-Oeste dos Estados Unidos, na solução de desafios ambientais complexos, tratando a região como um local onde todas as comunidades e a paisagem prosperam por meio de uma abordagem integrada face aos desafios ambientais, econômicos e sociais.

As florestas urbanas abrangem os dois focos de atuação do instituto: paisagens e comunidades. Como podemos tornar as comunidades mais resilientes e como usar a arborização urbana como ferramenta para isso? Como reduzir o lixo nas comunidades, quando grande parte dele é proveniente das florestas urbanas e das demolições? Ele poderia ser recuperado? Como podemos pensar a floresta urbana desse modo? Como tornar as edificações mais sustentáveis utilizando a madeira urbana como material ou o que podemos fazer em torno delas para construir comunidades mais resilientes? Como podemos usar as árvores e outra infraestrutura verde para reduzir o impacto das inundações e tempestades e como aumentar a resiliência face às mudanças climáticas? Como as árvores crescem e quais são as múltiplas formas de usá-las ao fim de seu ciclo de vida? E o que é necessário em termos de recursos financeiros, humanos, materiais e políticos para viabilizar tais mudanças, integrando gestores florestais e donos de terras, além de investigar se e como o setor privado, indústrias locais e outros negócios podem ser envolvidos no processo? A ideia é identificar todas as barreiras e oportunidades existentes, que possam ser utilizadas de forma produtiva e colaborativa, buscando os melhores resultados para o ambiente, para impacto na economia local, o melhor uso do investimento e o alinhamento da cadeia de fornecimento, criando um círculo para a cadeia de valor da floresta urbana.

As árvores urbanas oferecem muitos benefícios, e nós temos um número crescente de árvores e madeira urbana para gerenciar, que são oportunidades relacionadas ao impacto da mudança climática, espécies invasoras, estoque de moradias vagas e terras urbanas subutilizadas. Mas apesar disso, as árvores urbanas são difíceis de utilizar devido à diversidade das espécies, tamanhos, periodicidade das remoções, conflito entre propriedades públicas e privadas, coordenação e padronização de aquisições, falta de alinhamento da cadeia de valor do início ao final, políticas e processos inibem o melhor uso e de maior valor. Os objetivos devem ser retirar a madeira urbana do fluxo do lixo, criar trabalhos verdes e fornecer madeira obtida localmente para fabricantes.

Palavras-chave: madeira urbana, cadeia de valor, resiliência.
ABSTRACT

Delta Institute experience is presented, in collaborating with communities throughout Midwestern United Sates to solve complex environmental challenges, envisioning a region in which all communities and landscapes thrive through an integrated approach to environmental, economic, and social challenges.

Urban forests hitch both Delta's initiatives: landscapes and communities. How do we make communities more resilient and how do we use urban forestry as a tool to do that? How do we reduce waste in communities, when a lot of waste comes from the urban forests and from demolition? Could it be salvaged? How do we think the urban forest in that way? How do we make buildings more sustainable utilizing urban wood as material or what we can do around buildings to build more resilient communities? How do we use trees and other green infrastructure to reduce the impact of flooding and stormwater, and how to be more resilient against the impact of climate change? How the trees grow and what are the multiple ways we can use them at the end of their life cycle? And what is needed in terms of money, people, resources, and policies to make these changes happen, integrating the forester manager and the landowners, as well as investigating if and how the private sector, local industries and other businesses can be involved in the process? The idea is to identify all the existing barriers and opportunities that could be used in a productive collaborative way, seeking at the best results for the environment, the local economy impact, the highest invest use and the supply chain alignment, creating a circle for the urban forest value chain.

Urban trees provide many benefits, and we have a growing number of trees and urban wood to manage that are opportunities related to the impact of climate change, invasive species, vacant housing stock and underutilized urban land. But even though we have these opportunities urban trees are difficult to use because of the diverse species, sizes, timing of removals, public $x$ private land ownership, coordination and standardization of procurement, lack of aligned value chain from start to finish, policies and processes inhibit high and best use. The goals are to divert urban wood from the waste stream, to create green jobs and to provide locally sourced wood for manufacturers.

Keywords: urban wood, value chain, resilience. 